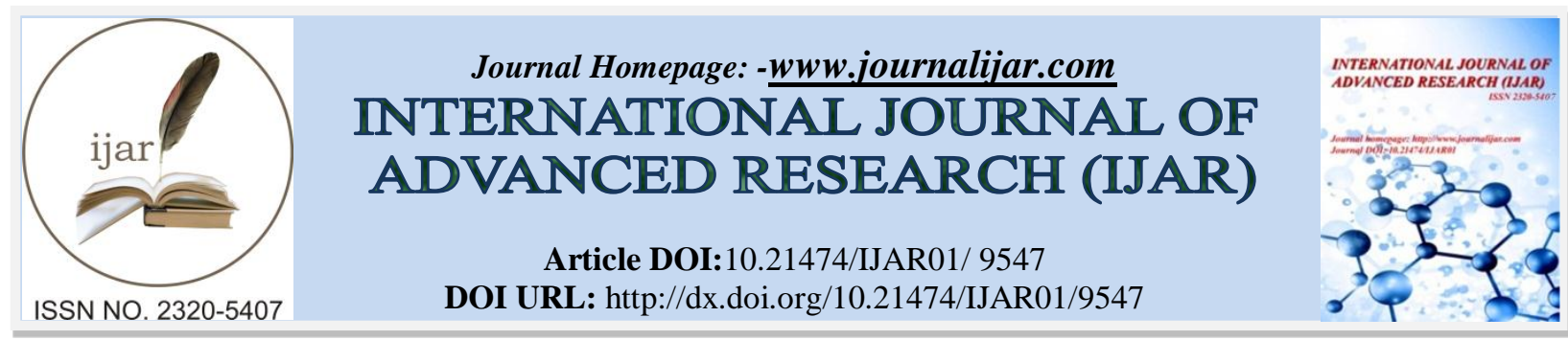

RESEARCH ARTICLE

\title{
SUSTAINABILITYSTATUS OF MULTI DIMENSIONS OF BEEF-CATTLE DEVELOPMENT IN INTEGRATED AGRICULTURALAREAS IN BONE BOLANGO REGENCY, GORONTALO PROVINCE.
}

Abdul Hamid Arsyad ${ }^{1}$, Z.Fanani ${ }^{2}$, B.A.Nugroho ${ }^{2}$ and Moch.Nasich ${ }^{2}$.

1. Postgraduate student of animal science, brawijaya university.

2. Lecturer of animal science, brawijaya university.

\section{Manuscript Info}

Manuscript History

Received: 08 June 2019

Final Accepted: 10 July 2019

Published: August 2019

Key words:-

Beef cattle, regions, integrated

agriculture, sustainability.

\section{Abstract}

The purpose of this study is to analyze the sustainability index and status of integrated beef cattle-based agricultural areas in Bone Bolango Regency, Gorontalo Province in terms of five dimensions: ecological, technological, economic, socio-cultural, legal and institutional dimensions. The method used in the study is a survey method using a systems approach. The study uses a multidimensional scaling (MDS) analysis method called RAPBANGKAPET and the results are expressed in terms of indexes and sustainability status. To find out the sensitive attributes that affect the index and the status of sustainability and the effect of the error, Leverage and Monte Carlo analyzes are performed. The results of the sustainability analysis are the economic dimension of $59.77 \%$, (sufficient) the technological dimension of $55.34 \%$ (sufficient), the economic dimension of $55.38 \%$ (sufficient), the socio-cultural dimension of $50.67 \%$ (sufficient) and the legal and institutional dimension of 66, 38\% (sufficient). Of the 53 attributes analyzed, there are 26 sensitive attributes that influence the increase in the index and the status of sustainability which is immediately addressed with a very small error level at 95 percent confidence level. The scenario of the sustainability strategy of developing integrated agricultural areas based on beef cattle based on the results of the analysis of the level of importance between factors obtained 6 key factors / determinants that have a strong influence and dependency between factors is not too strong, and those 6 key factors are; (1) Animal husbandry cooperatives, (2) Synchronization of central and local government policies, (3) Availability of agricultural extension institutions, (4) Availability of financial institutions (banks / credit), (5) Availability of animal health service places, (6 ) Cooperation Agreement (MoU) with other regions. Thus the six factors need to be managed properly and made various conditions that might occur in the future in order to realize the development of integrated integrated agricultural areas based on integrated beef cattle breeding in Bone Bolango Regency Province to support the implementation of government programs and regional autonomy.

Copy Right, IJAR, 2019,. All rights reserved.

Corresponding Author:-Abdul Hamid Arsyad.

Address:-Postgraduate student of animal science, brawijaya university. 


\section{Introduction:-}

Integrated agricultural area development program is one of the agricultural systems that can support sustainable agricultural development that emphasizes aspects of agribusiness-based agriculture, food crops, horticulture, plantations, animal husbandry and fisheries have begun to be held in various regions. The main characteristic of integrating plants with livestock is the existence of a mutually beneficial relationship between plants and livestock. The linkage can be seen from the integrated land division and the utilization of waste from each component. The interrelation between various components of the integration system is a triggering factor in encouraging the economic growth of farmers' communities and sustainable regional economic growth (Pasandaran, Djajanegara, Kariyasa and Kasryno, 2006).

Bone Bolango Regency as one of the regions in Gorontalo Province has considerable potential for the development of beef cattle farms where this region has an adequate supply of animal feed in the form of forages and agricultural waste as well as a strategic location because it is bordered by the provincial capital center. Based on the potential possessed, Bone Bolango Regency is one of the areas that has been determined by the Provincial Government based on Governor Decree Number 96/20 / III / 2015 as the location of Integrated Agricultural Area Development based on intercropping plants and livestock based on the potential of integrated agricultural areas, namely the conditions land, availability of water sources, Human Resources, location accessibility and production facilities. In addition, the integrated agricultural pattern is a pattern that integrates several business units that are managed in an integrated, ecologically oriented manner so as to obtain an increase in economic value, a high level of efficiency and productivity.

Beef cattle farms have been designated as one of the leading regional commodities by the government of Bone Bolango Regency in addition to poultry and other commodities. This policy has been strongly responded by the community based on facts on the ground, such as a) market opportunities that are still quite open where the market demand for beef cattle commodities is quite high, b) the potential and carrying capacity of land as a source of forage is available to support the development of cattle agricultural beef cattle, c) the suitability of agro-climate conditions, d) the culture of the community and the workforce in this area is very supportive of the development of beef cattle agricultural, e) the high level of local government support for beef cattle agricultural (BPS, 2016).

To get optimal results in the management of livestock, it must complete the criteria of sustainable development (sustainable development) which is a bridge between economic interests, social, cultural, and ecological sustainability (Suyitman et al., 2009). By implementing the development of integrated agricultural areas based on beef cattle farms in a sustainable manner it is hoped that it will have an impact on increasing the income and welfare of farmers so that it will also impact on the Regional Original Income (PAD), employment and for the application of technology to increase productivity, and the functioning of animal husbandry institutions (Suyitman , 2010).

The development of sustainable integrated agricultural areas is an integrated agribusiness development between livestock and plants. The development of integrated agricultural areas based on beef cattle farms has an important role in each area development activity that is strengthened through institutional management and partnerships with related parties. In addition, the role of the government, especially local governments, is crucial to the success in developing integrated agricultural areas that function as facilitators, dynamists, and motivators.

The development of a sustainable integrated cattle-based agricultural area in Bone Bolango Regency has a number of problems both related to the completeness of public facilities and infrastructure as well as supporting facilities and infrastructure. Another problem often faced is the low quality of rural human resources, the existing forms of institutions, and capital support in the context of regional development. However, an in-depth study has never been carried out so a study needs to be conducted on the "Status of Sustainability of Integrated Agricultural Areas Based on Beef Cattle Agricultural in Bone Bolango District, Gorontalo Province".

\section{Research purposes:-}

The purpose of this study is to analyze the sustainability of the system through the preparation of an index and formulate a policy for developing integrated agricultural areas based on beef cattle breeding, in Bone Bolango Regency, Gorontalo Province. 


\section{Research Methods:-}

Research Location and Time:-

The research location is in the area of Suwawa Subdistrict, Bone Bolango Regency, Gorontalo Province. The selection of Suwawa Subdistrict as the location of this research was conducted purposively based on several considerations, such as: 1) Suwawa Subdistrict is one of the locations determined by the provincial government as an integrated agricultural development area based on Gorontalo Governor Decree Number 96/20 / III / 2015. 2) Local government and breeders in Suwawa Subdistrict put beef cattle farms as one of the priority sectors to increase community income, 3) Strategic location because it is close to the center of the provincial capital, 4) Provincial and Bone Bolango government policies in supporting development beef cattle breeding business through its development programs. This research was conducted in March 2018 until September 2018 for 6 months.

\section{Research methods:-}

The method used in the study is a survey method using a systems approach. The system approach is used to formulate policies and strategic scenarios for the development of integrated agricultural areas based on beef cattle farms in Suwawa District, Bone Bolango District, which are multi-dimensional, involving various stakeholders, and across sectors.

The study begins by compiling an assessment (score) of each attribute on each dimension in order to assess the sustainability of the current system (existing conditions). Sensitive attributes that influence the value of the system sustainability index studied are then made as important factors in the system and analyzed the level of influence and dependency between these factors. In the final stage, policies and strategies for the development of integrated beef cattle-based beef cattle farms in Bone Bolango Regency can be formulated in Gorontalo Province.

\section{Population and Research Samples:-}

The population in this study were all breeders and stakeholders associated with this study, as well as all food crop land in Bone Bolango Regency.

The number of samples to be taken is that which can be considered to represent and understand the problem under study. The method of determining the sample in this study was determined using the Slovin formula as follows: (Kavanagh, 2001).

$$
n=\frac{N}{1+\mathrm{Ne}^{2}}
$$

\section{Details:}

$\mathrm{n}=$ Number of samples.

$\mathrm{N}=$ Number of population (head of farmer family).

$\mathrm{e}=$ Acceptable error $(10 \%)$.

The sampling of each village in this study is presented in Table 1 below

Table 1:-Number of samples of beef cattle farmers in each village

\begin{tabular}{|l|l|l|l|}
\hline Subdristict & Village & Farmer (Person) & Sample \\
\hline Suwawa & Huluduotamo & 140 & 33 \\
\hline & Boludawa & 120 & 28 \\
\hline Jumlah & Bube Baru & 112 & 27 \\
\hline Soura & & 372 & 88 \\
\hline
\end{tabular}

Source: 2017 Agriculture and Animal Husbandry Department data, processed

Furthermore, respondents from the experts were chosen deliberately (purposive sampling) of 10 (ten) people. Selected respondents have expertise in accordance with the field under study. Experts who will be an alternative choice to be respondents are 10 people representing all stakeholders such as farmer groups, beef cattle entrepreneurs, Head of Animal health service places, Head of Agriculture Service of Animal Husbandry and Animal Health of Bone Bolango Regency, Head of Agriculture, Animal Husbandry and Food Security Services of Gorontalo Province, Universities College (UNG Faculty of Agriculture), so that the selected experts are expected to be able to represent every element of the bureaucracy, academics (businesses), business actors, breeders, and associations / organizations concerned with beef cattle farms in Bone Bolango. 


\section{Data Types and Sources:-}

The type of data needed in the analysis of the sustainability of the development of integrated agricultural areas based on beef cattle farms is primary data and secondary data. Primary data in the form of attributes related to the five dimensions of development sustainability, namely: ecological, economic, social, technological / infrastructure, and legal / institutional dimensions. Primary data can be sourced from respondents and selected experts, as well as direct observations at the research location. Secondary data was obtained from the Department of Agriculture and Animal Husbandry of Bone Bolango Regency, BPS of Bone Bolango Regency, the results of research / literature studies, and all agencies related to this study.

\section{Data collection technique:-}

The method used in this study is the triangulation technique so that in this study obtained valid data. Moleong, 2004 states that, the validity of the data in research is one of the most important parts to determine the degree of trust from the results of research that has been done using triangulation techniques in data collection, then the data obtained will be more consistent so that it becomes a valid data and can scientifically justified.

According to Sugiyono (2013) triangulation is defined as data collection techniques that combine data from various data collection techniques and existing data sources. In this study, researchers used two types of triangulation, namely technical triangulation and source triangulation

\section{Data analysis method:-}

Data analysis method used in this research is Sustainability Analysis for the development of integrated areas based on beef cattle farms carried out with a Multidimensional Scaling (MDS) approach called the Rap-BANGKAPET (Rapid Appraisal Development of Animal Husbandry Development) which is the development of the Rapfish method used for assessing the sustainability status of fisheries catching (Kavanagh, 2001). This level of development analysis, expressed in the index of the sustainability of the development of integrated areas based on beef cattle farms. The analysis is carried out through several stages, those are: (a) determination of the attributes of the level of development of livestock-based areas covering five dimensions, such: economic, ecological, social and cultural, technological / infrastructure, and legal / institutional; (b) rating each attribute on an ordinal scale based on the criteria for the level of development of each dimension; and (c) compilation of indexes and the status of sustainability of integrated areas based on beef cattle farms (Dubrovsky, 2004).

The output of the results of this analysis is in the form of the status of sustainable development of beef cattle-based integrated areas for the five dimensions in the form of a score with a scale of 0-100. Sustainability categories are: a score < 25 means bad; score (26-50) means it is not yet complete; and a score of 51-75 means enough and a score of 76-100 means very good. This category is in accordance with the standards of Mersyah (2005), and Soesilo (2003). The score which is the value of the sustainability index for each dimension is shown in Table 2.

Tabel 2:-Status of sustainable development of integrated agricultural areas based on the index value of the results of the Rap-BANGKAPET analysis

\begin{tabular}{|l|l|}
\hline Index value & Sustainability status \\
\hline $0-25$ & Bad \\
$26-50$ & Less \\
$51-75$ & Sufficient \\
$76-100$ & Best \\
\hline
\end{tabular}

Sources : Mersyah, 2005; Soesilo,2003

\section{Research Result And Discussion:- \\ Sustainability Index:-}

In a research on the sustainability of the development of integrated agricultural areas based on beef cattle breeding in the region of Bone Bolango Regency, Gorontalo Province, the determination of the area sustainability index is determined on five dimensions of sustainability, such as the ecological dimension, the technological dimension, the economic dimension, the social dimension, and the legal and institutional dimensions with attributes and score the results of expert opinions. Based on the analysis using Rap-BANGKAPET (MDS), the sustainability index value for the ecological dimension is $59.77 \%$ with the sustainability status in the good category, the technology dimension for $55.34 \%$ with the sustainability status in the good category, economic dimension 55,38 with the sustainability status 
in the good category, the social and cultural dimension of 50.67 with the sustainability status in the good category and the legal and institutional dimension of $66.38 \%$ with the sustainability status in the good category. So that the index value in the future can continue to increase until it reaches the status of sustainability with a very good category, it is necessary to improve the sensitive attributes that affect the dimension index value. The attributes assessed by experts are based on the existing conditions of the region. The five-dimensional index value of the results of the Rap-BANGKAPET sustainability analysis is shown in Figure 1

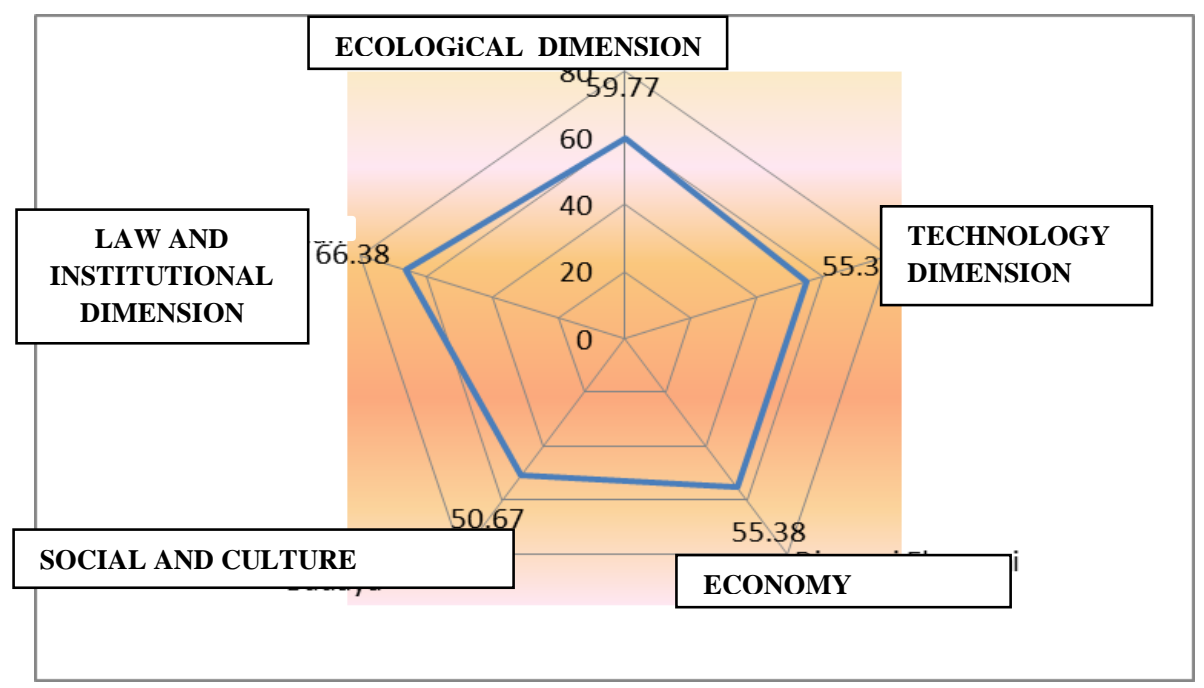

Figure 1:-Status of the sustainability of the development of integrated agricultural areas based on beef cattle farms in Bone Bolango Regency, Gorontalo Province

\section{Sustainability Analysis of the Ecological Dimension:-}

Based on Figure 1, the sustainability value for the ecological dimension is $59.77 \%$ included in the quite sustainable category. To see the sensitive attributes that influence the value of the ecological dimension sustainability index, a leverage analysis is performed using the Jacknife method. Based on the results of the leverage analysis, 8 attributes are sensitive to the ecological dimension of the sustainability index value: (1) the level of land use for agriculture and animal husbandry fully utilized, this is because some of the land which has a very low soil fertility level because it contains a lot of rocks; (2) The availability of slaughterhouses (RPH) is still very limited in the area of Bone Bolango Regency, only one unit is available and is included in type $\mathrm{C}$, so that in the future the availability of slaughterhouses needs to be increased so that the category is upgraded to type B according to the number of cattle slaughtering and the target intended market; (3) Farmers' cleanliness has not yet been fully considered by farmers. Livestock manure is left to accumulate in the cage for several days before being collected in a place and sometimes the conditions in the cage until muddy. This situation will cause environmental and livestock health problems. This needs to be considered by farmers so that cleanliness of the cage is maintained at all times, so that livestock health is more guaranteed and livestock productivity can be optimal, (4) Carrying capacity of animal feed at the research location is quite available. In the context of developing beef cattle, the carrying capacity of feed must be maintained so that the cattle that are cultivated can develop optimally, (5) The system for raising beef cattle generally is generally a traditional, semi-intensive breeding system. The technique used in traditional and semi-intensive maintenance systems is to use bonding patterns which move around, and are released, where animals are led by breeders to plantations where there is potential forage (HMT) or in pasture fields and cattle are bound for grazing. This activity is carried out in rotation to see which areas grow a lot of forage; sometimes cattle are bound from morning to afternoon, and then moved again until the afternoon. After the afternoon the cattle are put into a cage located in the yard of the house. In the future, it needs to be improved in an intensive maintenance system so that all livestock can be controlled both in terms of feed and animal health; (6) The level of soil fertility is generally moderate and low, this is because in the area most of the land consists of hills which contain a lot of rocks, so that in the future need special handling, especially in the provision of organic and inorganic fertilizers; (7) Frequency of floods and drought often occur in regional locations, if during the rainy season with high frequencies there will be flooding in several locations that have lowlands due to overflowing of the Bone river, this is due to irrigation or drainage systems are not properly considered, so that in the future need better handling, especially from the government, (8) Regional Spatial Planning (RTRW) in Bone Bolango Regency already exists but is still general in 
nature, not yet specifically detailed, so in the future it is necessary to make a special Spatial Plan for agriculture and animal husbandry .

\section{Leverage of Attributes}

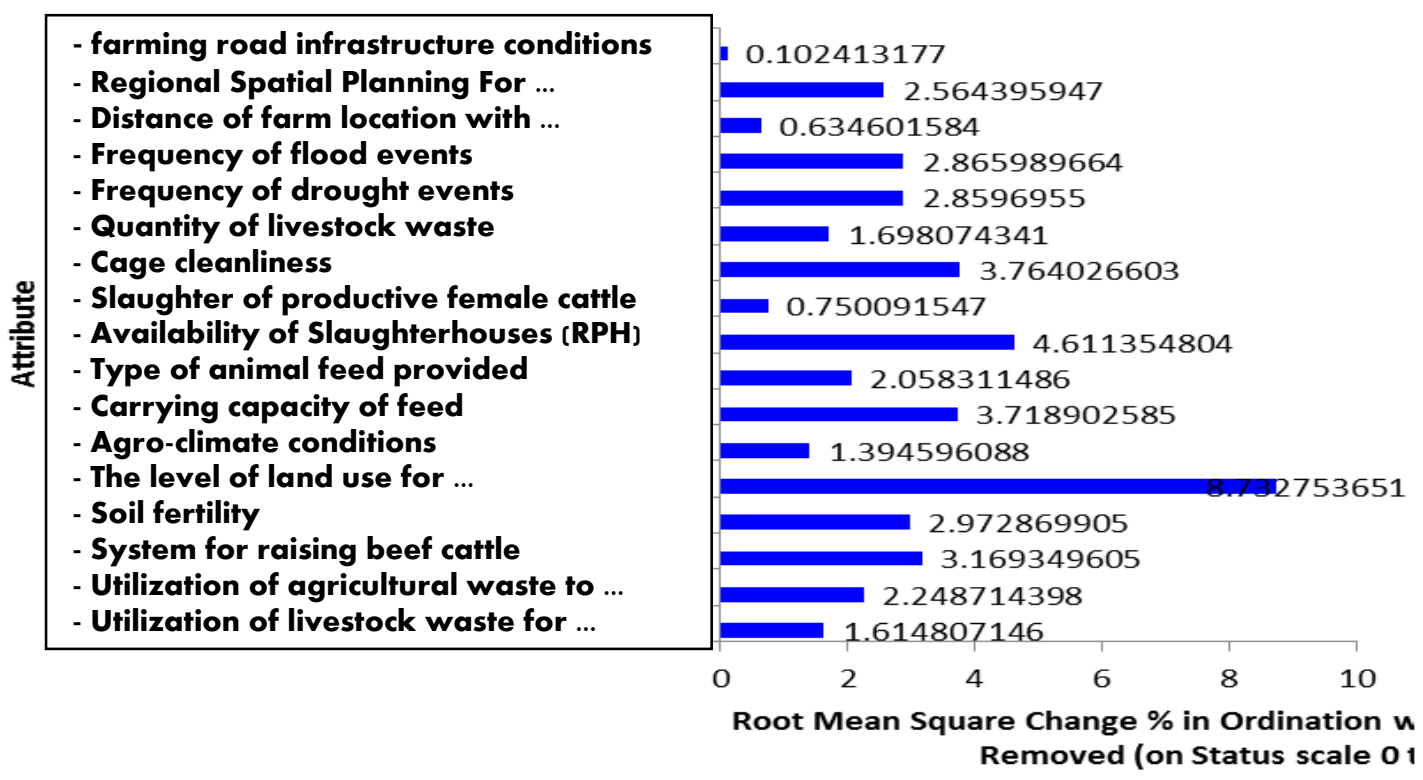

Figure 2:-The result of Ecological Dimension Leverage Analysis

Analysis of Sustainability in the Technology Dimension:-

Based on Figure 1, it shows the sustainability score of the development of integrated agricultural areas based on beef cattle breeding in Bone Bolango Regency, Gorontalo Province based on the technological dimension is 55.34\%. The non-metric MDS results on the technological dimension show that the value is between $51.0 \%-75.0 \%$ which means that the sustainability of integrated beef cattle-based agricultural area development in Bone Bolango Regency, Gorontalo Province based on the technological dimension is in the sufficient category. To find out the sensitive attributes to improve the sustainability status of the development of integrated beef cattle-based agricultural areas in Bone Bolango Regency, Gorontalo Province, leverage analysis using the Jacknife method was obtained. Sensitive attributes had an influence on the value of the technological dimension of the sustainability index, such: (1 ) Animal health service places are generally still concentrated in certain locations so that farmers sometimes have difficulty getting health care facilities. This condition must be a concern of the government so that in the future it is necessary to add more animal health service facilities that are spread throughout the villages and existing livestock groups; (2) The availability of information and transportation technology is very minimal in the research location, generally the information technology is still centralized so that to get access to information related to the development of beef cattle breeders must go to the information service centers in the Districts and districts. Likewise, the available transportation facilities are still very minimal, generally transportation used in the form of motorized vehicles, bentor or carts to take animal feed and to market agricultural products and livestock farmers / ranchers still experience difficulties in providing transportation facilities, thus hampering marketing activities, usually farmers are waiting for buyers to come to the location to buy their livestock, so that it will have an impact on the low prices received by farmers. 


\section{Leverage of Attributes}

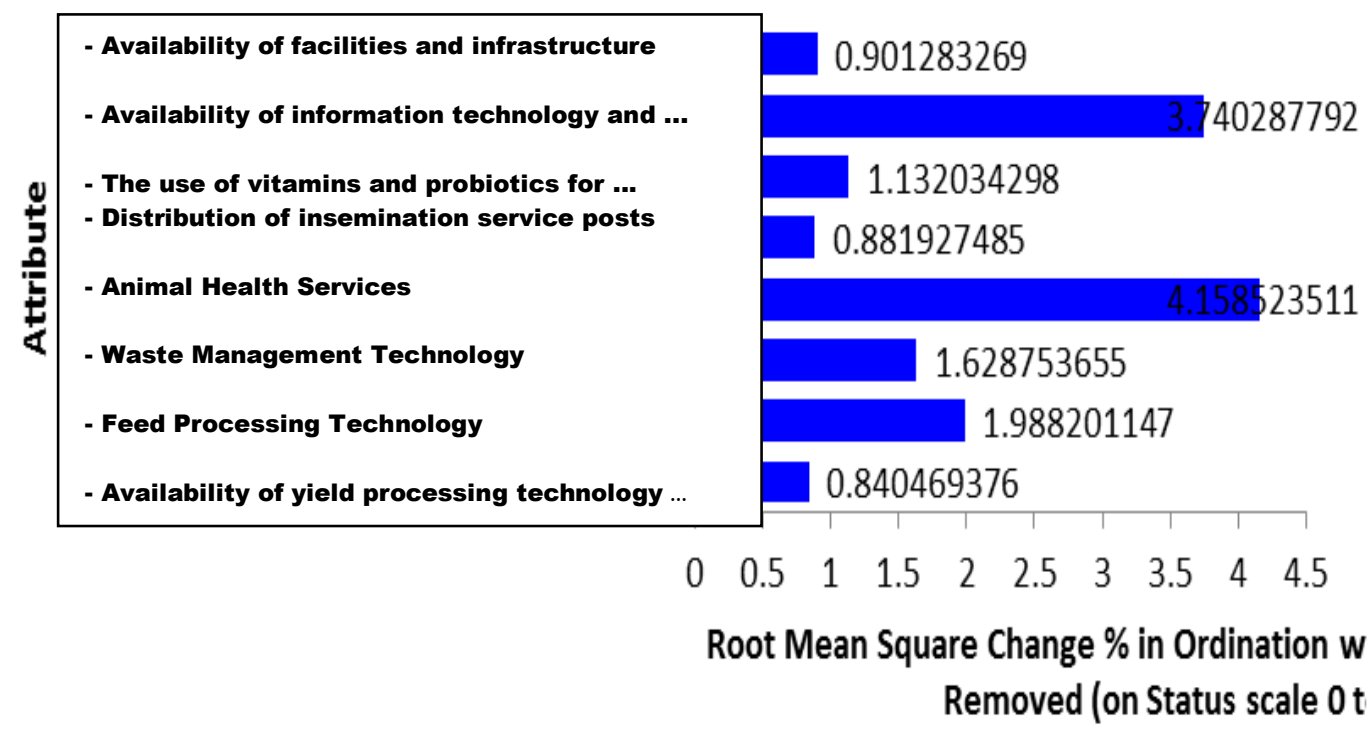

Figure 3:-Results of Leverage Analysis of Technology Dimensions

Economic Dimension Sustainability Analysis:-

Based on Figure it shows the score of the sustainability of the development of integrated agricultural areas based on beef cattle farms owned by Bone Bolango Regency, Gorontalo Province based on the economic dimension is $55.38 \%$. The non-metric MDS results on the economic dimension show that the value is between $51.0 \%-75.0 \%$ which means that the sustainability of integrated beef cattle-based agricultural area development owned by Bone Bolango Regency based on the economic dimension is in the moderate category. To find out the sensitive attributes to improve the sustainability status of the development of integrated agricultural areas based on beef cattle farms owned by Bone Bolango Regency, Gorontalo Province. Leverage analysis is used using the Jacknife method on the economic dimension attributes explained in Figure 7.

\section{Leverage of Attributes}

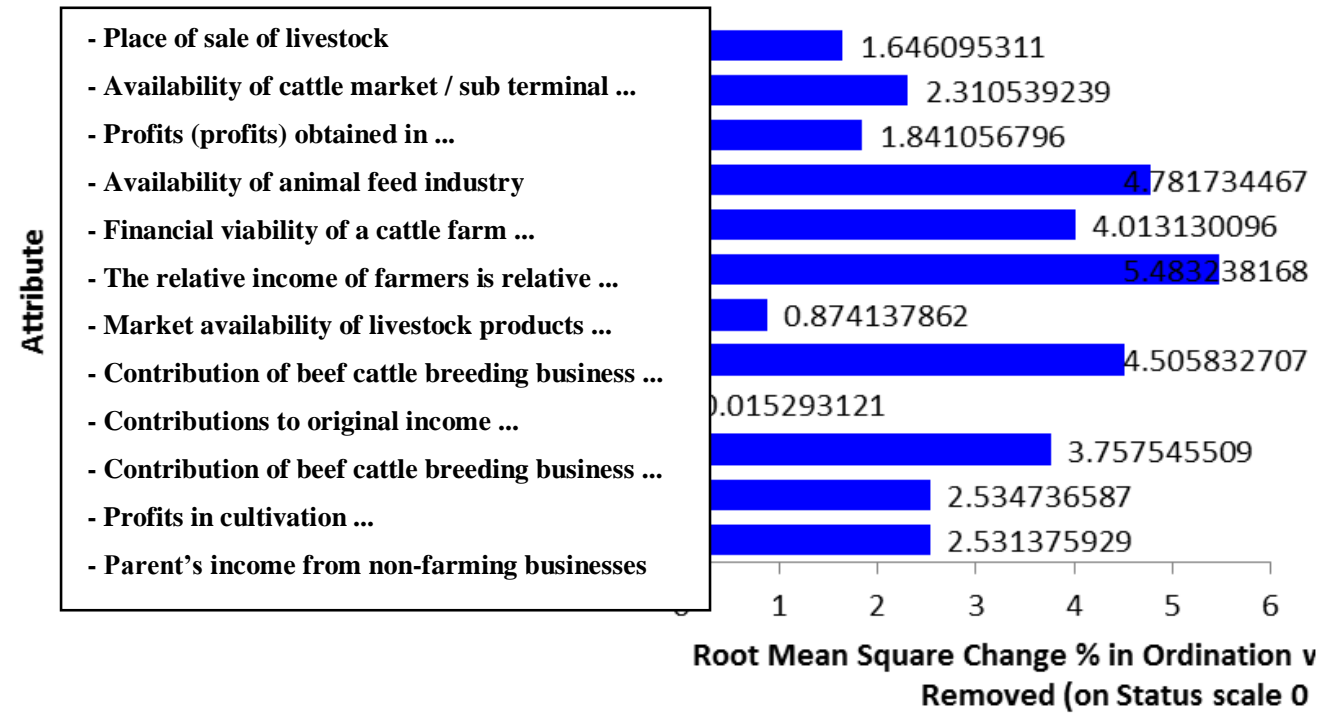

Figure 4:-Results of Leverage Analysis of Economic Dimensions

Leverage analysis results in Figure 7 Attributes that are sensitive to the value of the economic dimension of the sustainability index, there are: (1) The average farmer income to the Regional Minimum Wage (UMR) is still below, 
especially in traditional and semi-intensive maintenance systems, and a small portion who already have an average income above the $U M R$, so in the future it takes the role of extension workers to provide motivation to farmers to raise livestock with intensive systems; (2) The availability of the feed industry in this region is not yet available, in general, feed processing technology is still very simple. Farmers in providing food generally rely on food contained in the vicinity of the residence. Beef cattle breeders, for example, utilize natural grass which grows in grazing fields, gardens, forests, and utilizes agricultural waste and agricultural agro-industry waste that is sufficiently available in this region. Dependence on natural grass will face obstacles when the dry / dry season arrives. In order to ensure the availability of feed and the adequacy of livestock nutrition, the development of the feed industry is urgently needed in this area, especially the availability of agricultural products (corn) and agricultural waste (rice straw, corn leaves, cassava leaves, peanut leaves, and cassava shoots) and agricultural industrial waste (rice bran, tofu waste, and corncobs) that can be used for animal feed is quite widely available. With the existence of the animal feed industry in this region, in addition to meeting the needs of animal feed in their own area, the rest can be marketed to several regions, and in addition can absorb local labor and provide a multiplier effect on this region, so that the feed industry can contribute revenue to community and region; (3) The contribution to the total family income from the cattle business in this location is still very low, generally the income of farmers comes from the food crop agricultural business. Livestock business at this location is still a part-time business, so livestock sales are only done at any time. Usually they sell their cattle if it requires a large fee, for example for a wedding, send their children to school. In general, livestock business is used as family savings, except for fattening businesses with intensive maintenance systems, so the main goal is for family income; (4) The financial feasibility of beef cattle business in this location is only a small part, namely the intensive maintenance system, because the main purpose of maintenance in the intensive system is solely for business, so that the calculation of production costs is easy to do. Meanwhile, maintenance with traditional and semi-intensive systems cannot be said to be feasible, because the costs incurred for the production process are not in accordance with the number of livestock sales, because the purpose of maintenance is only for part-time businesses, whose sales are only carried out by farmers at any time.

\section{Analysis of Sustainability in Social and Cultural Dimensions:-}

Based on Figure 1, it shows the sustainability score of the development of integrated agricultural areas based on beef cattle breeding in Bone Bolango Regency based on social and cultural dimensions is 50.67\%. The non-metric MDS results on social and cultural dimensions show a value that is between $51.0 \%-75.0 \%$ which means that the sustainability of the development of integrated agricultural areas based on beef cattle breeding in Bone Bolango based on social and cultural dimensions is in the sufficient category. To find out the sensitive attributes to improve the sustainability status of the development of integrated agricultural areas based on beef cattle farms owned by Bone Bolango Regency, Gorontalo Province. Leverage analysis is used using the Jacknife method on the economic dimension attributes described in Figure 8.

Sensitive attributes have an effect on the value of the sustainability index of the socio-cultural dimension, which are: (1) the frequency of training and counseling in this area is classified as sparse. Bone Bolango Regency on average provides training and counseling to the community in the sub-district a maximum of 3 times a year and at least 1 time a year. Counseling and training materials are usually related to the socialization of livestock assistance, superior seeds, making feed from livestock waste and making organic fertilizer. Areas with promising beef cattle breeding potentials should often hold training and counseling related to advances in animal husbandry cultivation technology or the socialization of animal husbandry policies implemented by the government. Training and counseling must be done more often because there are many fundamental problems in animal husbandry cultivation such as cage hygiene that do not yet have a problem resolution; (2) The average level of education of farmers in this location is still classified as low level of education. Most farmers have received formal education, even at different levels. The average level of formal education that has been taken the most is elementary school, amounting to $69.32 \%$. The low level of formal education has an effect on the rate of adoption of innovation, changes in mindset and sensitivity to other social changes, therefore it needs non-formal education that can done to increase breeders' knowledge of the application of technology and innovation; (3) Community knowledge of environmental management is still very minimal. Environmental management, especially waste, is an effort to reduce the possibility of risks to the environment in the form of environmental pollution or damage, bearing in mind that this waste contains hazardous and toxic materials so that the potential for negative effects. Most of the farmers do not take any action in treating waste properly. They only dispose of waste around the location or in the river. In the future there needs to be training conducted by the government on environmental management between training in making liquid and solid fertilizer from livestock waste, so that waste is utilized properly and the environment is clean; (4) Farmer household growth (RTP). Farmer household growth is relatively slow. This shows that the 
incentive to raise beef cattle is reduced. At present, the local government is not innovating in encouraging people to raise beef cattle. The local government should encourage the growth of farmer households to support the development of beef cattle centers through integrated area development programs including the integration of livestock crops on dry land; (5) Family participation in managing livestock businesses in this area is still low. This situation should be changed and improved and for the future to be improved by inviting the whole family to participate in the management of animal husbandry business, so that the livestock business in this area is more advanced and rapid.

\section{Leverage of Attributes}

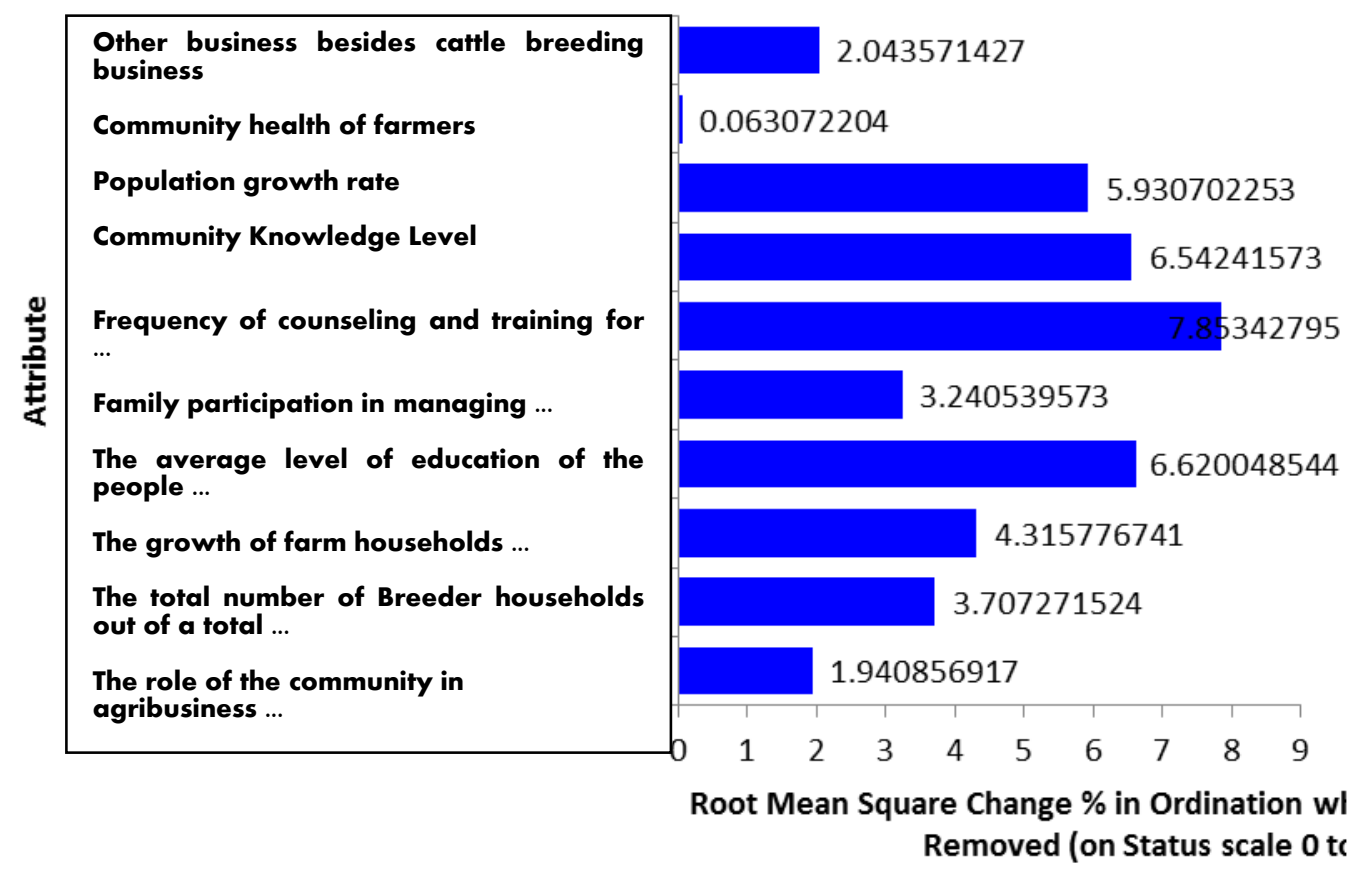

Figure 5:-Results of Leverage Analysis of Social and Cultural Dimensions

\section{Sustainability Analysis of the Legal and Institutional Dimensions:-}

Figure 4 shows the sustainability score of the development of integrated agricultural areas based on beef cattle breeding in Bone Bolango Regency, Gorontalo Province based on the legal and institutional dimensions of 66.38\%. The non-metric MDS results on the legal and institutional dimensions show a value that is between $51.0 \%-75.0 \%$ which means that the sustainability of integrated beef cattle-based farm development in Bone Bolango Regency Gorontalo Province based on the legal and institutional dimensions is in the category enough. To find out the sensitive attributes to improve the sustainability status of the development of integrated agricultural areas based on beef cattle farms owned by Bone Bolango Regency, Gorontalo Province. Leverage analysis is used using the Jacknife method on the economic dimension attributes which explained in Figure 6. 


\section{Leverage of Attributes}

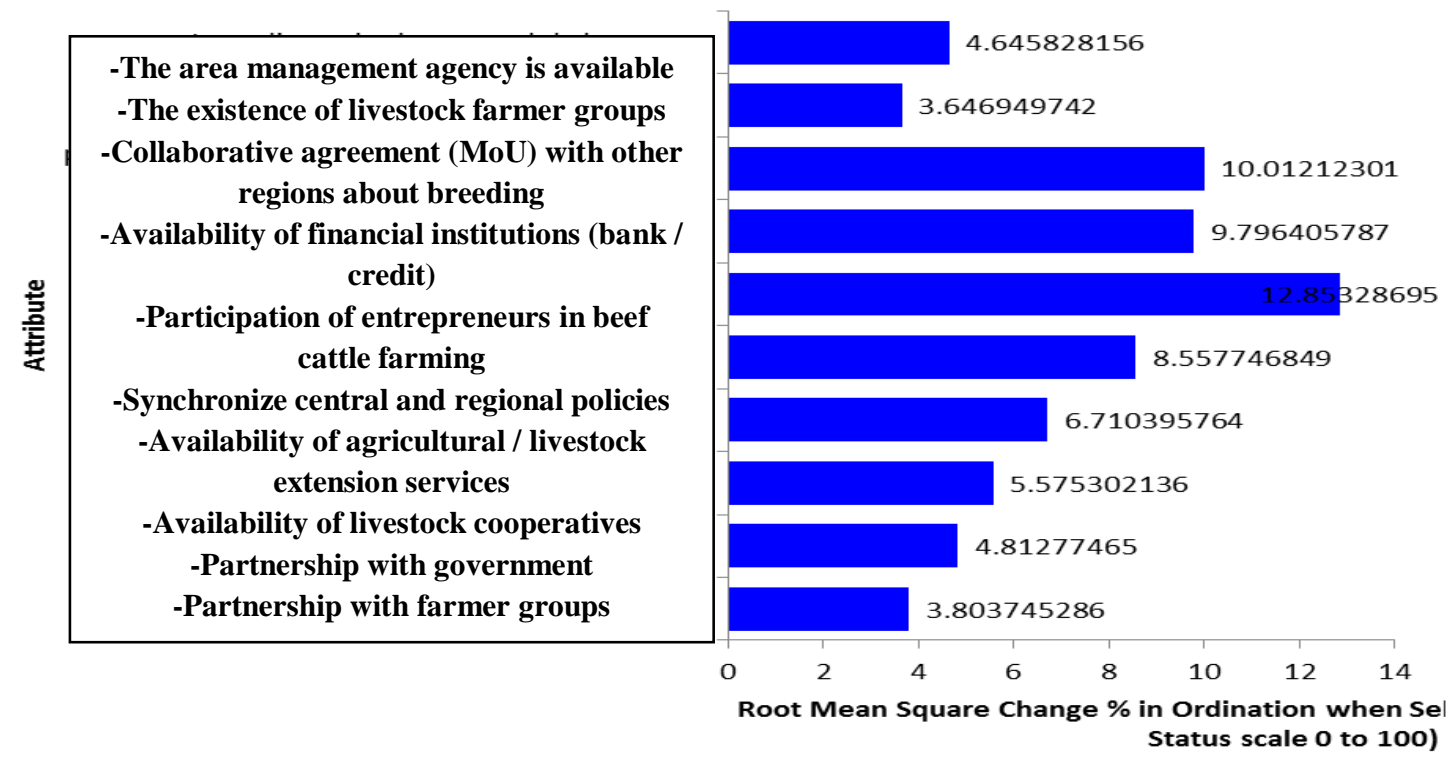

Figure 6:-Results of Leverage Analysis of Legal and Institutional Dimensions

Based on Figure 9, it is obtained that sensitive attributes have an effect on the value of the sustainability index of the legal and institutional dimensions, which are: (1) Participation of entrepreneurs in livestock business in this region is very minimal, if any but does not work well, this is caused by; a). the mechanism of group work that is running poorly, b). the use of collective cages is not optimal at all so the level of utilization of the cage facilities is low, c) the process of mentoring and guidance cannot be effective because the position of cattle cannot be kept in one collective cage, finally the existing livestock are scattered according to the domicile position of the breeders . The role of the government to overcome this problem is needed, so that in the future all systems will run well, and the participation of entrepreneurs will be further enhanced; (2) Cooperation agreements (MoU) with other regions are not going well, especially with breeders' groups. In general, cooperation agreements in the field of beef cattle breeding with other regions are still limited to the level of the Provincial Office, including agreements in the field of controlling and eradicating infectious diseases to livestock, and for cooperation agreements between farmer groups and other regions in this location do not yet exist. In the future, in order to increase livestock population, especially beef cattle in order to realize self-sufficiency in meat in 2018, it is necessary to have inter-regional cooperation in efforts to develop beef cattle breeding through research, education and training, even to the business financing model; (3) The availability of financial institutions (banks / credit) in this area is very little specifically to provide funds for livestock business activities. In order to improve the development of livestock business, the existence of financial institutions is needed to further facilitate the service of community economic activities. From the capital aspect, the banking sector still considers that beef cattle agribusiness activities as a business that has not yet been given priority to get business credit assistance. This is because, the banking sector still considers that beef cattle agribusiness is high risk and low in terms of income (low return); (4) Synchronization of central and regional policies concerning the development of integrated agricultural areas as stipulated in Regulation of the Minister of Agriculture No. 50/2012 concerning Guidelines for Developing Agricultural Areas. As a follow-up to the synchronization process of the agricultural area development plan in the provincial scope, so that the program components and activities contained in the Master Plan compiled in the province and all action plans drawn up by the district / city can be carried out properly, synchronizing the planning at the national scale. Synchronization at the Ministry of Agriculture level is intended as an effort to ensure the consistency of the Master Plan and the action plan with national level planning documents and provincial level planning documents. The scope of synchronized aspects includes the details in the action plans of each district / city, such as: (a) type of activity and volume, (b) location (sub-district / village), (c) implementation schedule, (d) implementing work units, (e) projections of funding needs and sources, (f) outputs and outcomes, and ( $\mathrm{g}$ ) indicators of success. The process and method of synchronizing the national scope development plan are as follows: 1) The Provincial Technical Team proposes the development of agricultural areas in the provincial scope which cannot be funded by the Provincial APBD, Regency/City APBD and 
community investment according to the program plan matrix as set out in the Action Plan in each district/city. 2) Provincial Technical Team proposes agricultural area development activities in provincial scope that cannot be funded by Provincial APBD, Regency/City APBD and community investment according to the program plan matrix as stated in the Action Plans in each district/city, 3) Technical Team The Province proposes the development of agricultural areas within the province which cannot be financed by the Provincial APBD, Regency/City APBD and community investment according to the program plan matrix as set out in the Action Plans in each district/city, 4) Coordination forum that can used in synchronizing proposed actions for the development of superior commodity areas at the provincial level is the National Agricultural Development Planning Conference and technical coordination meetings at the Ministry of Agriculture; (5) Agricultural extension institutions/Agricultural Extension Centers (BPP). Agricultural extension institutions already exist in this area, however, activities need to be increased, especially in the frequency of counseling and training in the management of livestock businesses so that they can gradually change the behavior of farmers in managing livestock businesses in a more advanced / intensive and sustainable direction. Counseling to farmers about cleanliness of the cages and processing of livestock waste into organic fertilizer is very urgent to be followed up immediately. Communities need to be given an understanding of some of the advantages of using / using organic fertilizer / manure, such as: organic fertilizer can increase soil nutrient elements, improve soil structure, increase soil cation exchange capacity (CEC), increase the ability of soil to retain water, enhance biology the soil, increasing the $\mathrm{pH}$ of the soil to neutral, increasing the availability of micro nutrients, and organic fertilizer does not cause environmental pollution. Likewise, BPP must be able to increase the role of the community in the availability of the agro-industry business sector. The existence of some livestock agroindustries in this region will absorb a lot of labor involved and with the presence of livestock agro-industries, the added value of livestock agribusiness is more optimal and can spur regional progress more quickly and contribute to higher regional GDP; (6) Animal Husbandry Cooperatives are one of the institutions that need attention in efforts to develop livestock agribusiness systems, remembering farmers as the majority and main actors in this system have weak capabilities in terms of capital, access to information, and technology. Cooperatives can be a medium for farmers to jointly build their businesses in an integrated manner from the upstream subsystem to the downstream subsystem, so that farmers can obtain better added value. At present, cooperatives operating among farmers are not yet as well developed as cooperatives operating among dairy farmers, for example the Indonesian Dairy Cooperative Association (GKSI); (7) The availability of an integrated agricultural area management body is very much needed in supporting the successful development of integrated agricultural areas. The agency's role includes: a) formulating programs, operational policies, and coordinating the planning and implementation of the development of integrated agricultural areas; b) encourage participation and non-governmental organizations in preparing master plans, programs and implementing integrated agricultural area programs; c) developing institutions, facilities and infrastructure to support the integrated agricultural development program;

\section{Multidimensional Sustainability Status:-}

The results of the multidimensional Rap-BANGKAPET sustainability analysis in the region of Bone Bolango Regency, Gorontalo Province for the development of the most developed cattle-based beef cattle agricultural based on existing conditions, obtained a sustainability index value of $72.57 \%$ and included in the category of fairly sustainable status. This value was obtained based on the assessment of 26 attributes of the five dimensions of sustainability, which are the ecological dimension, the technological dimension, the economic dimension, the sociocultural dimension, and the legal and institutional dimensions. The results of the multidimensional analysis by RapBANGKAPET regarding the sustainability of the Bone Bolango Regency for the development of the most developed cattle-based beef cattle breeding area can be seen in Figure 7. 


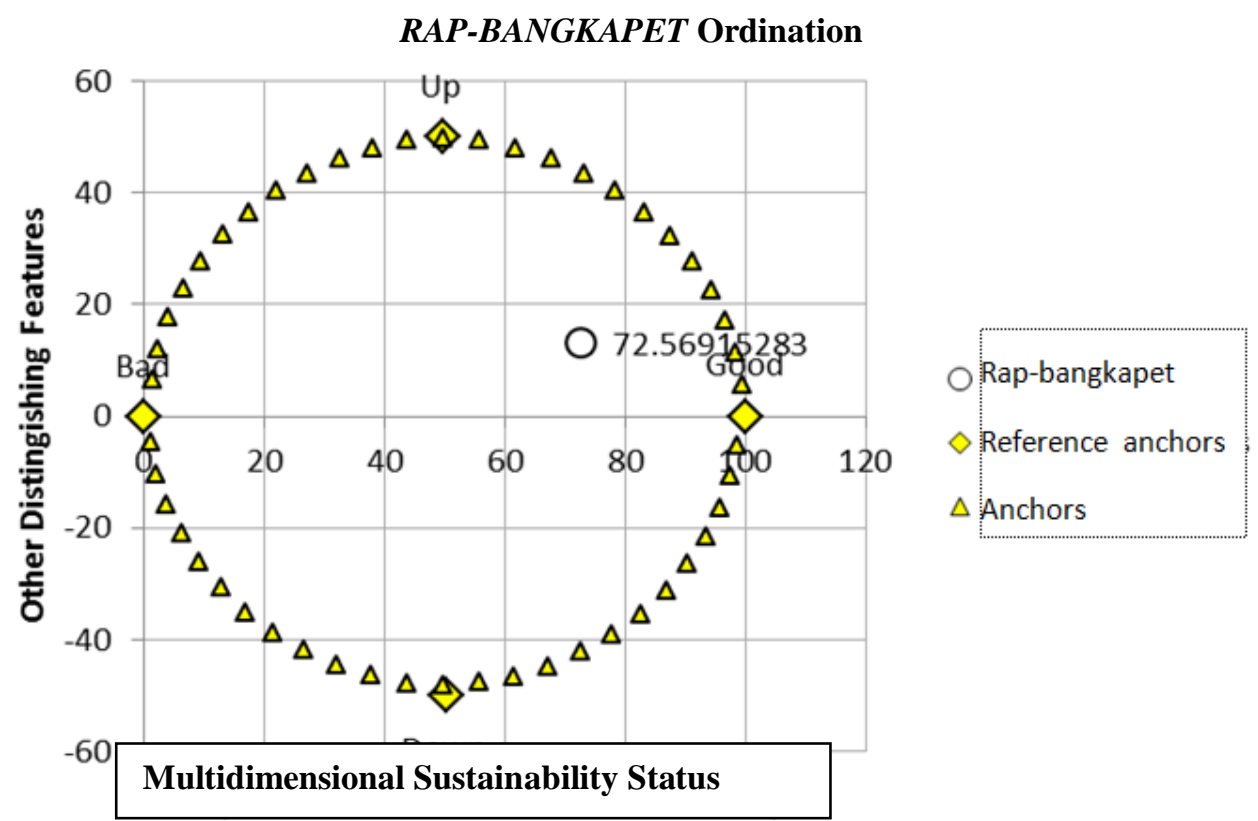

Figure 7:-Multidimensional sustainability index of Integrated Farm Area of Bone Bolango Regency, Gorontalo Province

The results of the Monte Carlo analysis show that the value of the sustainability index of the development of the most developed beef cattle-based farms in Bone Bolango Regency at a 95\% confidence level, shows results that do not experience differences with the results of Rap-BANGKAPET (multidimensional scaling = MDS). This means that errors in analysis can be minimized both in terms of scoring each attribute, variations in scoring because of differences in opinion are relatively small, and the process of data analysis carried out repeatedly is stable, and errors in inputting data and lost data can be avoided. The difference in the sustainability index values of the MDS and Monte Carlo analyzes is shown in Table 3.

Table 3:-Differences in the values of the sustainability index of the Monte Carl analysis with the Rap-BANGKAPET Analysis

\begin{tabular}{|l|l|l|l|}
\hline Sustainability Dimension & MDS & Monte Carlo & Differences \\
\hline Ecology & 59,77 & 58,21 & 1,56 \\
\hline Technology & 55,34 & 52,18 & 3,16 \\
\hline Economi & 55,38 & 51,69 & 3,69 \\
\hline Social Culture & 50,67 & 53,69 & 3.02 \\
\hline Law and Instititonal & 66,38 & 65,43 & 1,95 \\
\hline Multidimensional & 72,57 & 73,45 & 0,88 \\
\hline
\end{tabular}

The results of the Rap-BANGKAPET analysis show that all of the attributes examined in the sustainability status of the region of Bone Bolango Regency for the development of integrated agricultural areas based on beef cattle farms are accurate enough to provide better and accountable analysis results. The stress value obtained in the non-metric MDS analysis is 0.130, this value is below the provisions given by Kavanag and Pitcher (2004) which is 0.25 , so it can be stated that the resulting model has good accuracy. The stress value results are in line with the R2 value of 0.949 which means that the attributes of the environmental dimension can explain the environmental dimension of $94.9 \%$, while the remaining $5.1 \%$ is explained by other attributes not included in the model. R2 value above 0.9 means that the resulting model has good or reliable reliability, and can be used in further research. The stress value and the coefficient of determination can be seen in Table 4.

Table 4:-Results of Rap-BANGKAPET analysis for stress value and coefficient of determination R2

\begin{tabular}{|l|l|l|l|l|l|l|}
\hline Parameter & A & B & C & D & E & F \\
\hline Stress & 0,13 & 0,14 & 0,13 & 0,13 & 0,15 & 0,12 \\
\hline
\end{tabular}




\begin{tabular}{|l|l|l|l|l|l|l|}
\hline $\mathrm{R}^{2}$ & 0,95 & 0,95 & 0,95 & 0,95 & 0,89 & 0.95 \\
\hline Integration & 3 & 3 & 3 & 2 & 2 & 4 \\
\hline
\end{tabular}

Note: A = Dimension of Ecology, B = Dimension of Economy, C = Dimension of Socio-Culture, D = Dimension of Infrastructure - Technology, $\mathrm{E}=$ Dimension of Legal-Institutional, and $\mathrm{F}=$ Multidimensional

Scenario of Sustainability Strategy for Integrated Agricultural Area Based on Beef Cattle Agricultural:-

The strategy of developing an integrated sustainable agricultural area based on integrated beef cattle agricultural is carried out using a prospective analysis that aims to predict the likelihood that will occur in the future in accordance with the objectives to be achieved. Prospective analysis is carried out through three stages, namely: (1) identifying key factors in the future, (2) determining the strategic objectives and interests of the main actors, and (3) defining and describing the evolution of possible futures as well as determining sustainable regional development strategies in accordance with resources. Determination of the key factors in the analysis is taken from the key factors that are sensitive influence on the performance of the system results of the sustainability analysis. Based on the results of the sustainability analysis, 26 sensitive factors and attributes were submitted to the experts to be assessed and then prospectively analyzed. Prospective analysis results obtained 6 key factors as shown in Figure 8.

\section{Leverage of Attributes}

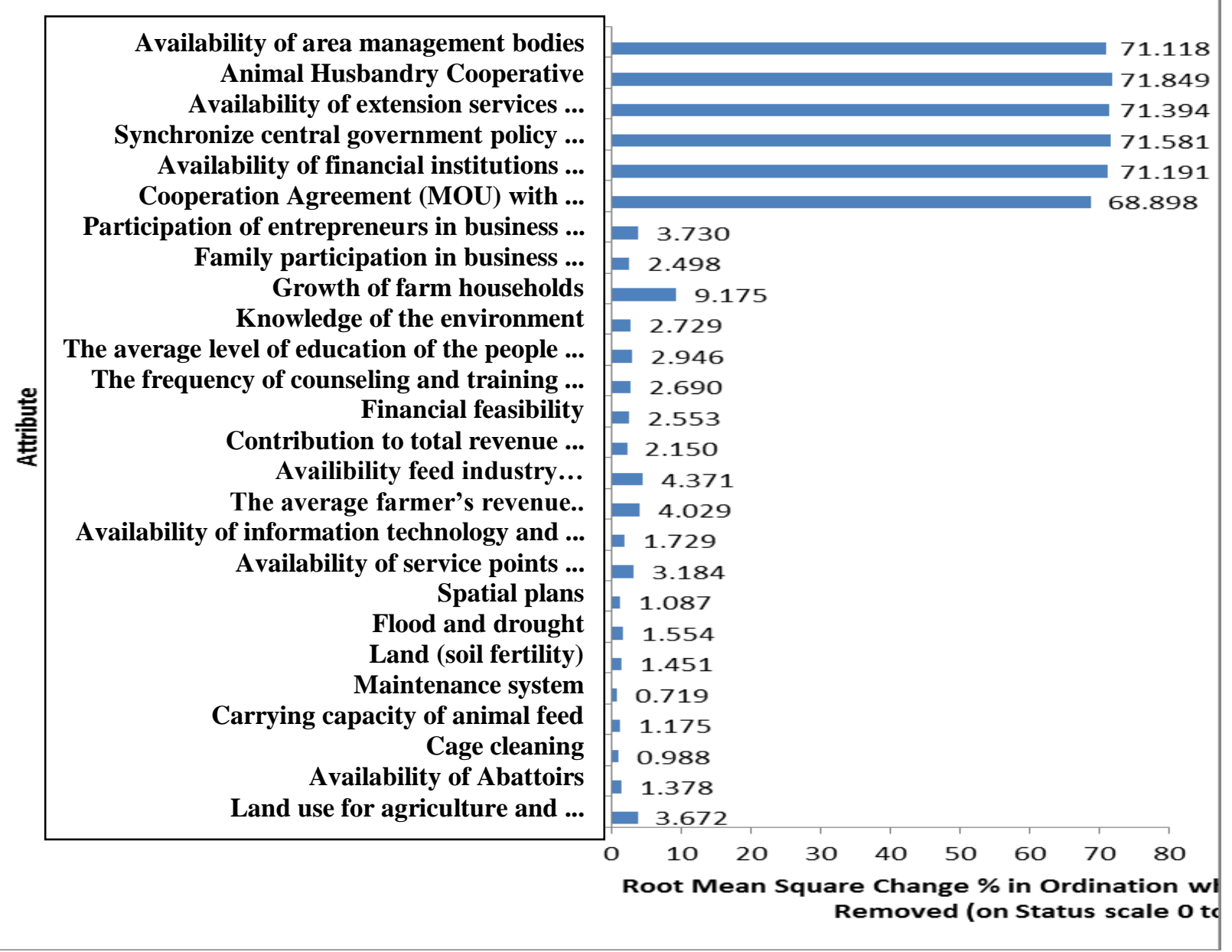

Figure 8:-Leverage Analysis Results of Sensitive Attributes of All Dimensions of Sustainability of Integrated Agricultural Areas

Based on the results of the previous analysis, various key factors were obtained that determine the success of the sustainable development of integrated beef cattle-based agricultural areas in order to lead to sustainable 
development that considers ecological, economic, and social aspects. This result has also taken into consideration the existing conditions of the region and the direction of development policies in general.

The draft sustainability policy for the development of integrated agricultural areas based on beef cattle breeding is formulated by taking into account the key factors that have been generated from the previous analysis. According to Godet et al. (1999), one of the objectives of conducting a prospective analysis is to translate strategies into planning, general objectives and strategies that emerge from prospective analysis that are useful for determining priorities in the planning process. This policy formulation is carried out through in-depth interviews with stakeholders and experts.

The formulation of the policy on the sustainability of the development of integrated agricultural areas based on beef cattle based on the results of the analysis of the level of importance between factors obtained 6 key factors / determinants that have a strong influence and dependency between factors is not too strong, those factor keys are:

1. Animal husbandry cooperatives.

2. Synchronization of central and regional government policies.

3. Availability of agricultural extension institutions.

4. Availability of financial institutions (bank / credit).

5. Availability of animal health service places (Animal health service places).

6. Cooperation Agreement (MoU) with other regions.

Thus the six factors need to be managed properly and made various conditions that might occur in the future in order to realize the development of integrated integrated agricultural areas based on integrated beef cattle breeding in Bone Bolango Regency to support the implementation of government programs and regional autonomy.

\section{Conclusions:-}

Conclusion:-

The results of the multidimensional Rap-BANGKAPET sustainability analysis of the development of the most developed cattle-based farms based on beef cattle based on existing conditions, obtained a value of a multidimensional sustainability index of $72.57 \%$ and included in the quite sustainable category. To achieve sustainable regional development, the performance attributes that need to be optimally and integrated from these five dimensions are institutional support both government and private (banks, cooperatives) that provide convenience in business capital loans with low interest, increased investment from entrepreneurs and outside investors to support the improvement of facilities and infrastructure in the region, cooperation with other regions in the field of animal husbandry, and the most important thing is that synchronization of central and regional government policies must be implemented in an integrated and sustainable manner.

\section{Bibliography:-}

1. Badan Pusat Statistik Kabupaten Bone Bolango, Kabupaten Bone Bolango Dalam Angka 2016. BPS Bone Bolango.

2. Barlas, Y. 1996. Formal Aspect of Model Validity and Validation System Dynamic. System Dynamic Review. Vol. 12. (http://www.Alabanyedu/cp/sds /sdcourses).

3. Dubrovsky, V. 2004. Toward System Principles: General system theory and the alternative approach. J. System Research. Vol 21 (2): 109-123.

4. Kavanagh. 2001. Rapid Appraisal of Fisheries (RAPFISH) Project: RAPFISH Software Description (for Microsoft Excel). Fisheries Centre. University of British Columbia.

5. Pitcher TJ. 2004. Rapfish, A Rapid Appraisal Technique for Fisheries, and Its Application to the Code of Conduct for Responsible Fisheries. Rome: Food and Agriculture Organization of the United Nations.

6. Moleong, L.J. (2011). Metodologi Penelitian Kualitatif Edisi Revisi. Bandung: PT Remaja Rosdakarya.

7. Pasandaran, E., Djajanegara, A., Kariyasa, K., dan Kasryno F. 2006. Integrasi Tanaman Ternak di Indonesia. Badan penelitian dan Pengembangan Pertanian. Jakarta.

8. Sugiono. 2013. Metode Penelitian Kuantitatif Kuantitatif dan RND. Bandung: Alfabeta

9. Sukandarrumidi. 2006. Metodologi Penelitian. Yogyakarta:Pers UGM.

10. Suyitman. 2010. Model pengembangan kawasan berkelanjutan berbasis peternakan sapi potong terpadu di Kabupaten Situbondo. Disertasi. Sekolah Pascasarjana IPB. Bogor. 